Pleione 12(1): 147 - 149. 2018.

(C) East Himalayan Society for Spermatophyte Taxonomy

doi:10.26679/Pleione.12.1.2018.147-149

\title{
Dioscorea hispida Dennst. (Dioscoreaceae) : a new addition to the state flora of Manipur, India
}

\author{
S. B. Ummalyma ${ }^{1}$, R. S. Devi ${ }^{2}$ and Sanjeet Kumar ${ }^{2,3}$ \\ ${ }^{1}$ Institute of Bioresources and Sustainable Development, A National Institute under Dept. Biotechnology \\ Govt. of India Imphal, Manipur \\ ${ }^{2}$ Biodiversity Conservation Division, Ambika Prasad Research Foundation, Imphal, India \& \\ Ambika Prasad Research Foundation, Bhubaneswar, India \\ ${ }^{3}$ Corresponding author,E-mail: sanjeet.biotech@gmail.com
}

[Received 31.05.2018; Revised 23.06.2018; Accepted 26.06.2018; Published 30.06.2018]

\begin{abstract}
Dioscorea hispida Dennst. (Dioscoreaceae) has been collected from the Imphal West district of Manipur, India. The taxon has identified as a new record to the flora of Manipur state. The ecology, associated flora and illustrations have been provided for easy identification in the field.
\end{abstract}

Key words: Dioscorea hispida, New record, Manipur flora, Associated species, ecology

\section{INTRODUCTION}

The state of Manipur, commonly known as "Jewel of India", is lying between $23^{\circ} 80^{\prime} \mathrm{N}$ to $25^{\circ} 68^{\prime} \mathrm{N}$ Latitudes and $93^{\circ} 03^{\prime} \mathrm{E}$ to $94^{\circ} 78^{\prime} \mathrm{E}$ Longitudes. It is one of the flora-rich eight states of North Eastern India. The $90 \%$ of the total area of the state is occupied by hilly regions which provides suitable platform for wild tuberous plants like many species of Dioscorea, Cheilocostus, Curculigo, Solena, Amorphophallus, Alocasia etc. During the survey of floral wealth of Manipur, authors found a species of Dioscorea L. (Dioscoreaceae) at the Imphal West district. After morphological analysis and literature survey (Majumder et al. 2009) it was identified as D. hispida Dennst., which is yet to be recorded for flora of Manipur. Dioscorea L. is a monocotyledonous genus of tuberous herbaceous climbers, twinning to $20 \mathrm{~m}$ or more with suitable support. The genus comprises about 600 species distributed all over the world, especially in tropical and subtropical regions (Trimanto \& Hapsari 2015). Out of these, about 91 species are reported from North-Eastern part of India. Among those 30 species from Arunachal Pradesh, 19 species from Assam, 16 species from Meghalaya, 12 species from Sikkim, 10 species from Tripura and 4 species from Manipur (Saikia et al. 2011; Goswami et al. 2013; Pradhan et al. 2015; Paul et al. 2017; Kumar et al. 2017). The present record of the occurrence of D. hispida in Manipur showed its distribution up to Manipur-Myanmar boarder within the Indo-Burma Biodiversity Hotspot area in India.

\section{Taxonomic treatment}

Dioscorea hispida Dennst., Schlüssel Hortus Malab. 33. 1818; Gamble, Fl. Madras 3: 1511(1055). 1928; Prain \& Burkill, Ann Roy. Gard. (Culcutta) 14(1): 188t. t.77. 1936; Burkill in Steenis, Fl. Males.1.4: 318. 1951. D. daemona Roxb., Fl. Ind.3: 805. 1832; Wight, Icon.t. 811. 1844; Hook.f. in Fl. Brit. India 6: 289. 1892; Prain, Bengal Pl. 2: 1066. 1903; Haines, Bot. Bihar \& Orissa, parts V - VI: 1123. 1924. [Dioscoreaceae]. [PLATE - I] 


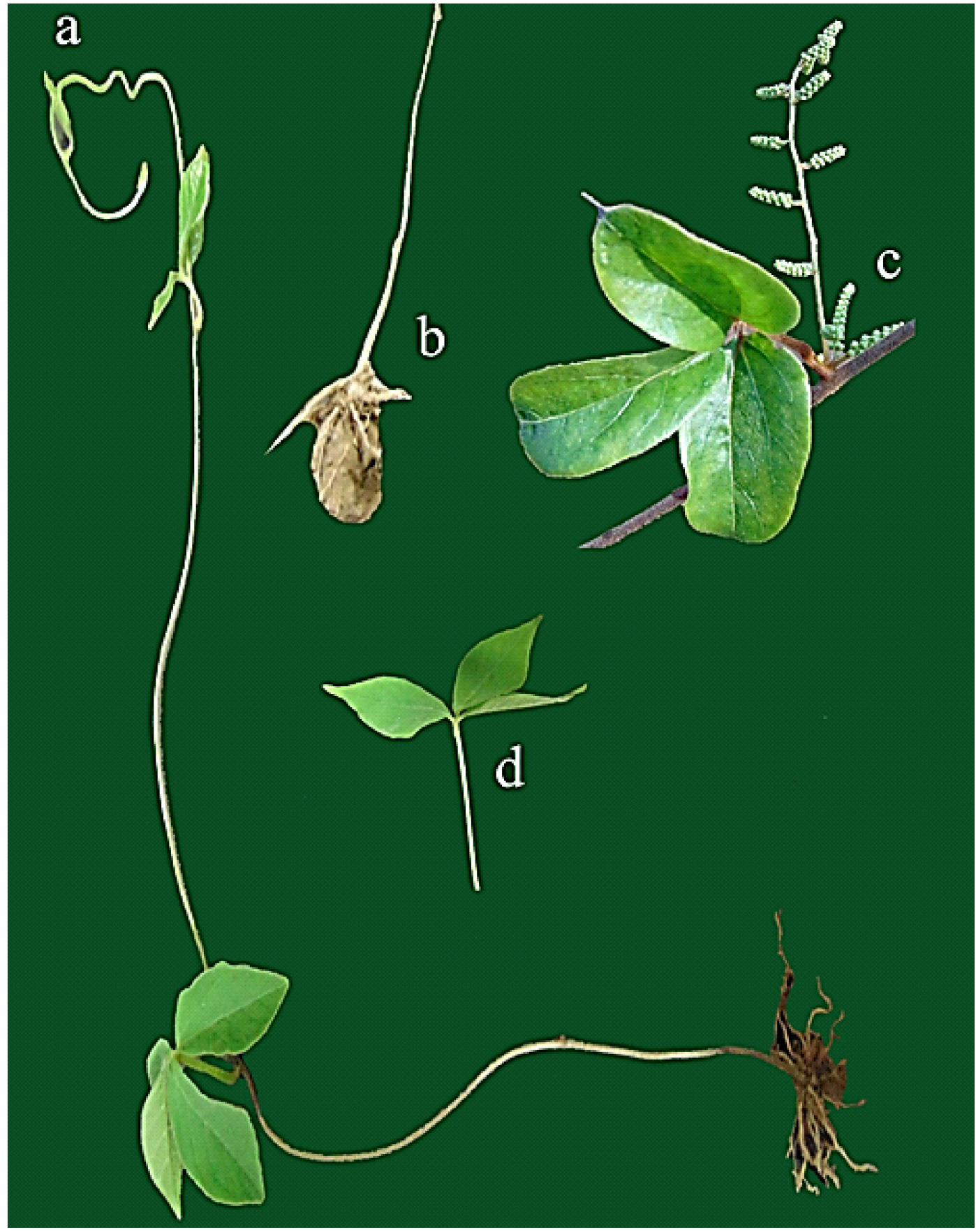

PLATE I. Dioscorea hispida: Vegetative parts. (a) Whole plant, (b) Tuber (c) Leaf and Inflorescence, (d) Twig

Strong geophytic twiner; stem twining to the left, prickly, tomentose when young; tubers subglobose or irregular, up to $38 \mathrm{~cm}$ in diam., covered with many fibrous-roots. Leaves 3foliolate; petioles $6-35 \mathrm{~cm}$ long, prickly, glabrous or finely pubescent; leaflets $6.2-33.5 \mathrm{x}$ $3.5-15 \mathrm{~cm}$, the terminal one elliptic, entire, caudate-acuminate, $3-5$-costate, base tepering; 
lateral leaflets much oblique, shortly 2-lobed, gibbous, broader than long; petiolules 2-19 $\mathrm{mm}$ long. Male flowers in dense, short, narrowly oblong axillary spikes, $6-8 \mathrm{~mm}$ long; panicles pubescent, prickly, $15-26 \mathrm{~cm}$ long; rachis pubescent or villous; bracts of flowers small, orbicular, 1-1.6 mm diam., concave, pubescent; inner perianth lobes oblong-obovate; anthers 6 , perfect, minute; female spikes 2-nate, simple, pubescent or tomentose. Capsules quadrately oblong, $3.5-5.8 \times 1.5-3.1 \mathrm{~cm}$, truncately rounded, smooth. Seeds winged at the base.

Flowering: June - August; Fruiting: August - September

Specimen examined: INDIA: Manipur, Imphal West district, N 24 $88^{\prime} 69.33^{\prime \prime}$ and E $93^{\circ} 90^{\prime}$ 69.33", S Kumar - APRFH-M08, dated 19.05.2018.

Habitat \& Ecology: D. hispida is found in regions where temperature is moderate and found to be grown in association with Dioscorea bulbifera L., Cissampelos pareira L., Celastrus paniculatus Willd., Lygodium flexuosum (L.) Sw., Melastoma malabathricum L., Dioscorea pubera Blume, Mikania micrantha Kunth, Azadirachta indica A.Juss., Elephantopus scaber L., Tinospora sinensis (Lour.) Merr., etc.

Conservation status: The present scenario of the plant shows no threats but there is possibility of threats in future due to current trend of massive deforestation and drastic climate changes over the entire region.

\section{Acknowledgements}

Authors are thankful to the Director, Institute of Bioresources and Sustainable Development, Imphal, Manipur and local communities of collected areas.

\section{LITERATURE CITED}

Goswami, N.; Borthakur, S.K. \& Hore, D.K. 2013. The genus Dioscorea Linnaeus [Dioscoreaceae] in Assam, India. Pleione 7(1): 73 - 83.

Kumar, S.; Das, G.; Shin, H.S. \& Patra, J.K. 2017. Dioscorea spp. (A Wild Edible Tuber): A Study on Its Ethnopharmacological Potential and Traditional Use by the Local People of Similipal Biosphere Reserve, India. Front. Pharmacology 8: 1 - 17.

Majumder, K.; Saikia, B. \& Datta, B.K. 2009. A new recorded for Tripura, India (Dioscorea hispida Dennst.). Pleione 3(2): 224 - 226.

Paul, C.; Debnath, A.; Chanda, R, \& Debnath, B. 2017. Taxonomical note, new distributional record and traditional use for Dioscorea wallichii Hook.f. (Dioscoreaceae) of Tripura, North-East India. Annals Pl. Sci. 6(2): 1868 - 1871

Pradhan, A.; Chettri, A. \& Gurung, S. 2015. Diversity and Distribution of Genus Dioscorea in Sikkim Himalaya, India: an application of DIVA-GIS. Intn. J. Envir. Biodiv. 6(3): $29-31$.

Saikia, B.; Rawat, J.S.; Tag, H. \& Das, A.K. 2011. An investigation on the taxonomy and ecology of the genus Dioscorea in Arunachal Pradesh, India. J. Frontl. Res. 1: $44-$ 53.

Trimanto \& Hapsari, L. 2015. Diversity and utilization of Dioscorea spp. Tuber as a alternative food source in Nganjuk regency, East Java. Agrivita, 37(2): 97 - 107. 